\title{
Sites of Formation of the Serum
}

\section{Proteins Transferrin and Hemopexin}

\author{
G. J. Thorbecke, H. H. LIEM, S. KNight, K. Cox, and \\ U. MULlER-EbERHARD
}

From the Department of Pathology, New York University School of Medicine, New York 10016, and the Department of Biochemistry, Scripps Clinic and Research Foundation, and Division of Pediatric Hematology, University of California at San Diego, La Jolla, California 92037

\begin{abstract}
A B S T RACT Sites of synthesis of hemopexin and transferrin were determined by culturing various tissues of rabbits and monkeys in the presence of labeled amino acids. Labeling of the serum proteins was examined by means of autoradiographs of immunoelectrophoretic patterns as well as by precipitation in the test tubes employing immunospecific antisera. Good correlation was seen between the results obtained by the two different methods. The liver was found to be the only site of many tissues studied that synthesized hemopexin. Transferrin production was observed in the liver, submaxillary gland, lactating mammary gland, testis, and ovary.
\end{abstract}

\section{INTRODUCTION}

The two major serum proteins in heme and iron metabolism are the $\beta$-glycoproteins hemopexin and transferrin. Growing interest in the heme-binding serum protein hemopexin has recently developed in response to the observation that its concentration changes from the normal in a variety of diseases. A fall, reciprocal to plasma heme levels, is encountered in hemolysis (1-3) and in certain porphyrias ( 4 and our unpublished observations), and $a$ rise in hemochromatosis (5), diabetes mellitus (6), and malignancies (7). Clinical investigations on the effect of various disease states on the serum level of the iron-binding serum protein, transferrin, are abundant. Greatest attention has been drawn to the elevation

Dr. Knight performed this work during the tenure of an International Public Health Fellowship 1 FO5 TWO 1571-

01. Her present address is Division of Surgical Science, Clinical Research Centre, Harrow, Middlesex, England.

Dr. Muller-Eberhard is a Career Development Awardee of the National Institute of Arthritis and Metabolic Diseases.

Received for publication 20 June 1972 and in revised form 25 October 1972. in iron deficiency and the decrease in inflammatory reactions (8).

Preliminary findings $(9,10)$ suggested that hemopexin is formed by the liver. Previous studies in this laboratory indicate that transferrin is produced in liver (11-14) as well as in lymphoid tissues and isolated macrophages of the mouse, rat, and neonatal rabbit (15, 16). However, in the guinea pig (16), adult rabbit (14), sheep (17), monkey $(12,18)$, and human $(12,18)$, the liver but not the lymphoid tissue synthesized transferrin. More recent observations point to the ectodermal glandular tissues (19) as yet another site of transferrin synthesis.

The present work aims at establishing where hemopexin is produced, and at determining whether transferrin is formed at sites other than the liver in the rabbit and monkey. Incorporation of labeled amino acid into the two serum proteins by various tissues in vitro was studied by autoradiography $(\mathrm{AR})^{\mathbf{1}}$ of immunoelectrophoretic (IE) patterns $(11,20,21)$. These qualitative data were compared with the total amount of radioactivity found within the proteins precipitated by their specific antibodies.

\section{METHODS}

Animals. The animals were young adult New Zealand rabbits. The majority of animals were male. Submaxillary glands were taken from fetal (22 days gestation) rabbits and pooled without regard to sex. Four rabbits received intramuscular injections of $2 \times 2.0 \mathrm{ml}$ and four other rabbits $2 \times 0.5 \mathrm{ml}$ of paratyphoid vaccine (Wyeth Laboratories, Marietta, Pa.) 12-24 hours before death. Two rabbits were injected intramuscularly with $2 \times 2 \mathrm{ml}$ turpentine and another rabbit was bled $60 \mathrm{ml}$ from the ear vein $24 \mathrm{~h}$ before death. Such pretreatments were previously shown to stimulate serum protein production in the liver $(13,14)$. The

${ }^{1}$ Abbreviations used in this paper: AR, autoradiography; BGG, bovine gamma globulin; IE, immunoelectrophoretic. 


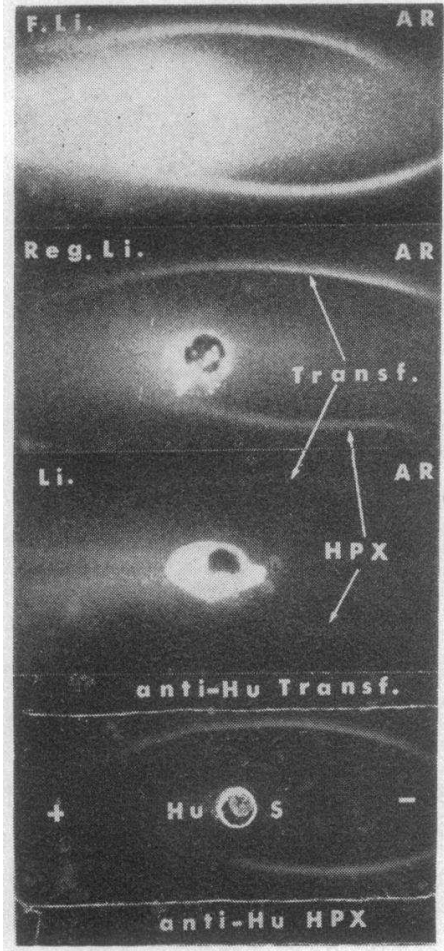

FIGURE 1 Autoradiographs (AR) of IE patterns prepared with culture fluids from monkey, fetal liver (F. Li.), regenerating liver (Reg. Li.), and normal liver (Li.), using normal human serum ( $\mathrm{Hu}$. S.) as the carrier. Patterns were developed by rabbit antisera to human transferrin (Transf.) and hemopexin (HPX). Note varying degrees of labeling of both proteins in these liver cultures.

Rhesus monkey tissue cultures were the same as those described in a previous study (14). All monkeys except one were female.

Cultures. The methods for preparing tissue cultures were described in detail elsewhere (14). 100-200 mg of minced tissue, or $1-3 \times 10^{7}$ peripheral blood leucocytes were incubated in roller tubes at $37^{\circ} \mathrm{C}$ for $24-48 \mathrm{~h}$ with $2 \mathrm{ml}$ of a medium containing $1 \mu \mathrm{Ci}$ of $\mathrm{L}-\left[{ }^{14} \mathrm{C}\right]$ isoleucine and $\mathrm{L}-\left[{ }^{14} \mathrm{C}\right] l \mathrm{y}-$ sine each, per $\mathrm{ml}$ (Schwarz Bio Research, Orangeburg, N. Y.; specific activity $1000-2000 \mu \mathrm{Ci} / \mathrm{mg}$ ). After the culture period, media were dialyzed against $0.015 \mathrm{M}$ phosphate buffer, $\mathrm{pH} 7.2$, and concentrated exactly 15 -fold by lyophilization.

Antigens and antisera. The serum proteins studied are readily recognized in the complex IE patterns of whole serum: albumin by its characteristically high concentration and fast mobility, transferrin by its capacity to bind radioactive iron (22), and hemopexin by its peroxidase activity when complexed with heme (23). In addition, purified hemopexin of rabbit and human was utilized for identification (24).

Monospecific antisera to the rabbit and human proteins were obtained from goats and sheep according to an immunization schedule recently reported (25). These antisera were employed for both the IE patterns as well as for the specific precipitation of the individual proteins from the complex mixtures. The monkey serum proteins cross-reacted strongly with the human proteins (unpublished findings); antisera to the human proteins could therefore be used confidently for the analysis of AR of the IE patterns prepared with monkey tissue culture fluids. Development of rabbit antisera to whole human serum was previously described (12). A sheep antiserum to whole rabbit serum was prepared in the Otisville Laboratories of the New York City Department of Health $(14,16)$.

Analysis of culture fluids. Qualitative analyses were performed by the method employing AR of IE patterns (11, 12). Appropriate carrier (added once to the antigen well before application of the concentrated culture fluid) and antisera dilutions were utilized to achieve sharp precipitation arcs on the IE patterns. After washing and drying the slides, autoradiographs were documented by using Kodak Royal Pan film (Eastman Kodak Co., Rochester, N. Y.) and an exposure time of $2 \mathrm{wk}$.

Semiquantitative analyses were carried out on $5.0-\mu 1$ portions of culture fluids after addition of $5.0 \mu \mathrm{l}$ of a normal rabbit serum (NRS) carrier of known albumin, transferrin, and hemopexin content. In short, most of the nonspecific binding of the radioactive material was first removed by precipitation of bovine gamma globulin (BGG) and antiBGG added at equivalence. The supernatant was collected after incubation at $4^{\circ} \mathrm{C}$ overnight and centrifuged in a $\mathrm{Pr}-2$ International centrifuge (International Equipment Co., Needham Heights, Mass.) at $2400 \mathrm{rpm}$ for $30 \mathrm{~min}$. To a measured portion of the supernate was added an amount of antirabbit albumin 2-3 times in excess of equivalence to the carrier albumin. The supernate of this precipitation, collected under the conditions described above, was divided into two equal portions. To one of each was added either antirabbit transferrin or anti-rabbit hemopexin, again in an amount exceeding equivalent carrier antigen content by twoto threefold.

The four precipitates resulting from the analysis of one culture fluid were washed three times in buffered saline $(\mathrm{pH}$ 7.4) and were then dissolved in $0.1 \mathrm{ml} 1 \mathrm{~N} \mathrm{NaOH}$ at $56^{\circ} \mathrm{C}$, mixed with $2 \mathrm{ml} \mathrm{Beckman} \mathrm{Biosolve} \mathrm{no.} 2$ (Beckman Instruments, Inc., Fullerton, Calif.), and poured into scintillation vials. Each tube was rinsed once with $2 \mathrm{ml} \mathrm{MeOH}$, and three times with $2 \mathrm{ml}$ toluene fluor. These rinses were added to the scintillation vials and the radioactivity measured in a Parkard scintillation counter (Packard Instrument Co., Inc., Downer's Grove, Ill.).

Comparison of degrees of radioactivity. Comparison of degrees of radioactivity between different proteins is not readily possible with the methods used. The autoradiographic method is extremely dependent on the sharpness of the precipitation arc, which tends to be different for each individual protein, and on the area of the slide over which the protein spreads itself during electrophoresis. For instance, antigen excess parts of the precipitation arc such as the middle of the albumin arc tend to show up less dark on the autoradiographs (Fig. 1). The grading of density of AR images was done separately for each protein. Thus a $3+$ to $1+$ for albumin does not indicate a similar intensity as does a $3+$ to $1+$ for hemopexin.

Comparisons between different tissues are also hindered by the fact that the specific activity of the $\left[{ }^{14} \mathrm{C}\right]$ amino acids in the cultures is greatly influenced by the amount of cold amino acids added to the tissue. This does not influence the ratios of radioactivity in proteins produced within the same culture, but the amino acid content of the individual proteins does. On a molar basis the ratios of human albumin to transferrin to hemopexin for the combined amino acids, lysine and isoleucine, is $64: 85: 37(26)$. If the same specific activity is present for both amino acids this means that 
TABLE I

Incorporation of $\left[{ }^{14} \mathrm{C}\right]$ Amino Acid into Transferrin, Hemopexin, and Albumin by Rabbit Tissues In Vitro

\begin{tabular}{|c|c|c|c|c|c|c|c|c|c|}
\hline \multirow[b]{2}{*}{ Tissue } & \multicolumn{3}{|c|}{ Transferrin labeling } & \multicolumn{3}{|c|}{ Hemopexin labeling } & \multicolumn{3}{|c|}{ Albumin labeling } \\
\hline & Strong & Weak & Negative & Strong & Weak & Negative & Strong & Weak & Negative \\
\hline Liver & $8^{*}$ & 3 & 2 & 6 & 5 & 2 & 8 & 5 & 0 \\
\hline Submaxillary gland & $1+$ & 1 & 0 & 0 & 0 & 2 & 0 & 0 & 2 \\
\hline Lactating mammary gland & 2 & 0 & 0 & 0 & 0 & 2 & 0 & 0 & 2 \\
\hline Nonlactating mammary gland & 0 & $1 \S$ & 1 & 0 & 0 & 2 & 0 & 0 & 2 \\
\hline Spleen & 0 & () & 4 & 0 & () & 4 & () & 0 & 4 \\
\hline Thymus & () & () & 1 & 0 & () & 1 & () & 0 & 1 \\
\hline Ovary & 2 & 0 & 0 & () & 0 & 2 & 0 & 0 & 2 \\
\hline Testis & 0 & 2 & 0 & 0 & 0 & 2 & 0 & 0 & 2 \\
\hline Bone marrow & 0 & 0 & 1 & 0 & 0 & 1 & 0 & 0 & 1 \\
\hline Blood leukocytes & 0 & 0 & 3 & 0 & 0 & 3 & 0 & 0 & 3 \\
\hline Muscle & 0 & 0 & 1 & 0 & 0 & 1 & 0 & 0 & 1 \\
\hline
\end{tabular}

* Number of individual tissues with this degree of labeling on autoradiographs of IE patterns.

‡ Submaxillary gland from fetal rabbit.

$\$$ Mammary gland from nonlactating rabbit which had raised a litter several months before.

transferrin will obtain approximately 2 times as much label per molecule as hemopexin, and albumin slightly less than transferrin.

\section{RESULTS}

Qualitative determination of sites of transferrin and hemopexin synthesis. Good agreement was observed between the results with rabbit and monkey tissues. The only site of hemopexin and of albumin synthesis in both species was the liver (Tables I and II). Of the 13 rabbit liver cultures, only 2 lacked detectable labeling of transferrin and hemopexin. The degree of labeling obtained on AR of IE patterns of liver culture fluids for both hemopexin and albumin, as also for transferrin, was higher with liver cultures from turpentine- or high dose paratyphoid vaccine-injected animals than with liver cultures from rabbits receiving low doses of paratyphoid vaccine or left uninjected. This is in agreement with previously reported data (14). In monkeys, the degree of serum protein labeling in fetal and regenerating liver cultures was much higher than in those of normal adults (Table II, Fig. 1). Among the seven adult monkey liver cultures, five failed to show demonstrable hemopexin labeling and only five of the seven livers showed radioactivity in transferrin.

Labeling of transferrin was observed in cultures from a number of other tissues in addition to the liver ( $\mathrm{Ta}$ bles I and II and Fig. 2). Among these were submaxillary gland and testis in both the rabbit and monkey, ovary in the rabbit though not in the monkey (compare ref. 18), and lactating mammary gland in the rabbit (not examined for the monkey). These observations coincide with unpublished data which show transferrin synthesis in the murine lactating mammary gland, testis, and ovary. In addition, a separate study (19) showed that the transferrin concentration, although low in human milk, is higher in rabbit colostrum and milk than in rabbit serum. Two of the six monkey spleens and one of the four monkey bone marrow cultures showed weak labeling of transferrin with the monospecific antiserum.

TABLE II

Incorporation of $\left[{ }^{14} \mathrm{C}\right]$ Amino Acid into Transferrin and Hemopexin by Rhesus Monkey Tissues In Vitro

\begin{tabular}{|c|c|c|c|c|c|c|}
\hline \multirow[b]{2}{*}{ Tissue cultured } & \multicolumn{3}{|c|}{ Transferrin labeling } & \multicolumn{3}{|c|}{ Hemopexin labeling } \\
\hline & Strong & Weak & $\begin{array}{l}\text { Nega- } \\
\text { tive }\end{array}$ & Strong & Weak & $\begin{array}{l}\text { Nega- } \\
\text { tive }\end{array}$ \\
\hline Fetal liver & $2 *$ & 1 & $\mathbf{0}$ & 2 & 1 & 0 \\
\hline Regenerating liver & 1 & $\mathbf{0}$ & 0 & 1 & $\mathbf{0}$ & 0 \\
\hline Normal adult liver & 0 & 5 & 2 & $\mathbf{0}$ & 2 & 5 \\
\hline Salivary gland $\S$ & 1 & 5 & 0 & $\mathbf{0}$ & 0 & 6 \\
\hline Spleen & 0 & 2 & 4 & 0 & $\mathbf{0}$ & 6 \\
\hline Fetal spleen & 0 & 0 & 2 & $\mathbf{0}$ & 0 & 2 \\
\hline Ovary & 0 & 0 & 2 & 0 & 0 & 2 \\
\hline Fimbriae of oviduct & 0 & 0 & 4 & 0 & 0 & 4 \\
\hline Testis & 1 & 0 & 0 & $\mathbf{0}$ & 0 & 1 \\
\hline Vas deferens & $\mathbf{0}$ & 0 & 1 & 0 & 0 & 1 \\
\hline Bone marrow & 0 & $1 \ddagger$ & 3 & 0 & 0 & 4 \\
\hline Blood leukocytes & 0 & 0 & 2 & 0 & 0 & 2 \\
\hline Kidney & 0 & 1 & 5 & 0 & 0 & 6 \\
\hline
\end{tabular}

* Number of individual tissues with this degree of labeling on autoradiographs of IE patterns.

$\ddagger$ Faint labeling of part of the line only.

\& Submaxillary and parotid gland cultures gave similar results. One-sixth of the animals donating submaxillary gland were male. 


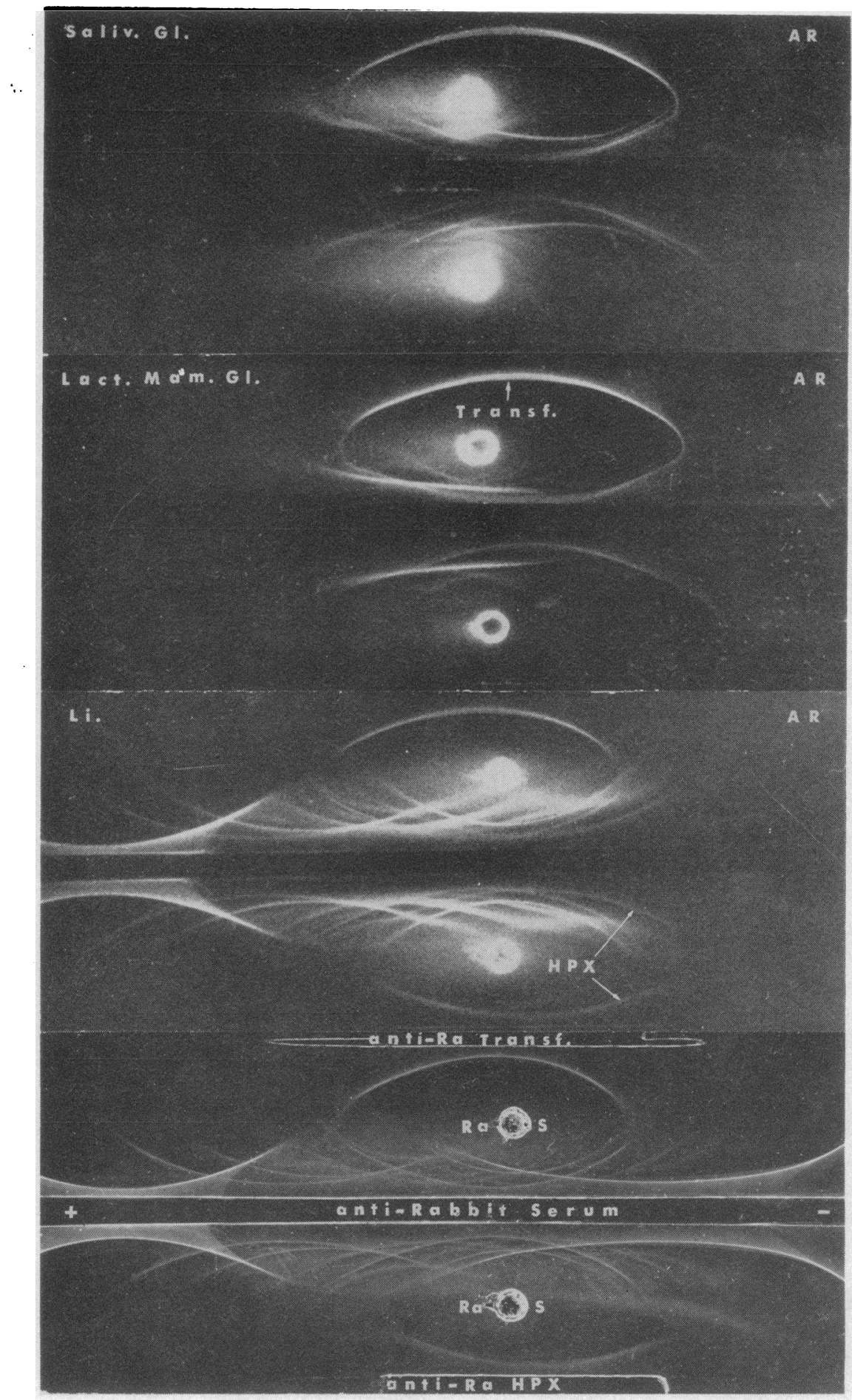

FIGURE 2 Autoradiographs (AR) of IE patterns prepared with culture fluids from rabbit salivary gland (Saliv. Gl.), lactating mammary gland (Lact. Mam. G1.), and liver ( $\mathrm{Li}$.) using normal rabbit serum (Ra. S.) as the carrier. Patterns were developed by goat antisera to rabbit transferrin (Transf.) and hemopexin (HPX) as well as by sheep antiserum to whole rabbit serum. Note labeling of transferrin in all three culture fluids and of hemopexin, albumin, and a variety of other serum proteins in the liver culture. 
This had not previously been observed in studies using rabbit anti-whole human or monkey serum $(12,18)$. A variety of other monkey organs not included in the tables were also examined with negative results for all three proteins. These included four lung, four thyroid, and three duodenal cultures.

Semi-quantitation of $\left[{ }^{14} \mathrm{C}\right]$ amino acid incorporation into albumin, transferrin, and hemopexin in rabbit tissue cultures. The amounts of radioactivity in albumin precipitated by specific anti-albumin from individual liver culture fluids are recorded in Table III. They agree well with the autoradiographic results. Of the four liver cultures examined with strong labeling of albumin on autoradiographs all had counts in their albumin precipitates above $170 \mathrm{cpm} / \mu 1$ of culture. The five cultures with weaker albumin labeling (Table I) showed a range of $10-110 \mathrm{cpm} / \mu 1$ of culture fluid in their albumin precipitates.

The counts per minute in the monospecific precipitates, prepared in the supernatant of the albumin precipitation, also showed fair agreement with the results of AR of IE patterns, for both transferrin and hemopexin. The cultures, nos. 1-6 (Table III), were strong + , while the remaining cultures, nos. 7-8 (Table III), were weak + or negative. The liver cultures with strong labeling in transferrin and hemopexin were all from rabbits which had been injected with a high dose of paratyphoid vaccine $12-24 \mathrm{~h}$ prior to death.

Some measurements were also made with other rabbit tissues. The control BGG precipitates brought down far more counts than did the albumin precipitates from most of these culture fluids. This was particularly true for spleen and salivary gland cultures. The counts adhering to the albumin precipitates, particularly when in the same range or lower than those in control precipitates, probably represented nonspecifically adhering labeled material.

The remaining supernatants in some cases still contained radioactivity that was brought down by antitransferrin, even though additional BGG control precipitates in such supernatants generally did not. Again there was good agreement with results of AR of IE patterns. In particular, all the cultures which exhibited strong labeling of transferrin on autoradiographs contained above $100 \mathrm{cpm} / \mu 1$ of culture fluid in the transferrin precipitates. For the cultures recorded in Table I that were also examined with the semi-quantitative method, the following amounts of radioactivity were found in the transferrin precipitates: ovary cultures 112 and $119 \mathrm{cpm}$; testis 41 and $38 \mathrm{cpm}$; lactating mammary gland $228 \mathrm{cpm}$ as opposed to nonlactating mammary gland $14 \mathrm{cpm}$; and salivary gland from a fetal rabbit $381 \mathrm{cpm}$ as opposed to $58 \mathrm{cpm}$ in the adult rabbit salivary gland. The radioactivities in the hemopexin precipi-
TABLE III

Semi-Quantitative Determination of $\left[{ }^{14} \mathrm{C}\right]$ Amino Acid Radioactivity Associated with Albumin, Transferrin, and Hemopexin in Rabbit Liver Culture Fluids

\begin{tabular}{|c|c|c|c|c|c|c|c|}
\hline \multirow[t]{2}{*}{$\begin{array}{c}\text { Culture } \\
\text { no. }\end{array}$} & \multirow{2}{*}{$\begin{array}{c}\begin{array}{c}\text { Control } \\
\text { ppt. }\end{array} \\
c p m / \mu l\end{array}$} & \multicolumn{2}{|c|}{ Albumin } & \multicolumn{2}{|c|}{ Transferrin } & \multicolumn{2}{|c|}{ Hemopexin } \\
\hline & & $c p m / \mu l$ & $\begin{array}{c}A R \text { of } \\
I E P\end{array}$ & $c p m / \mu l$ & $\begin{array}{c}A R \text { of } \\
I E P\end{array}$ & $c p m / \mu l$ & $\begin{array}{c}A R \text { of } \\
I E P\end{array}$ \\
\hline $1 *$ & 25 & $216 \ddagger$ & +++8 & $34 \|$ & ++ & $35 \|$ & $+t$ \\
\hline 2 & 109 & 267 & $+t+$ & 59 & ++ & 36 & ++ \\
\hline 3 & 74 & 207 & +++ & 37 & ++ & 12 & ++ \\
\hline 4 & 40 & 172 & +++ & 56 & $+t$ & 27 & + \\
\hline 5 & 52 & 110 & $+t$ & 34 & $+t$ & 56 & + \\
\hline 6 & 8 & 28 & + & 12 & + & 9 & + \\
\hline 7 & 5 & 11 & $\mathbf{w}+$ & 19 & $\mathbf{w}+$ & 12 & $w+$ \\
\hline 8 & 8 & 10 & tr. & & & $\mathbf{0}$ & - \\
\hline
\end{tabular}

IEP, immunoelectrophoretic patterns.

* Rabbits $1,2,3$, and 5 were injected with high, rabbits 7 and 8 with low doses of paratyphoid vaccine; rabbit no. 4 was bled $60 \mathrm{ml}$ and no. 6 was injected with turpentine (see Methods).

† Precipitated from supernate of BGG-anti BGG ("control ppt.") immune precipitate.

\$ The degree of labeling in precipitates was judged independently for each protein and graded from +++ (very strong) to trace (barely discernible) or - (negative).

II Precipitated from portions of supernatant of albumin precipitate by antitransferrin or anti-hemopexin.

tates were insignificant when compared to background levels ranging from 0 to $1 \mathrm{cpm}$ for salivary gland and from 7 to $15 \mathrm{cpm}$ for mammary gland.

\section{DISCUSSION}

The present results suggest that the liver is the main site of hemopexin and albumin production in both the rabbit and the Rhesus monkey. Preliminary semi-quantitative measurements in human fetal liver cultures (Muller-Eberhard, unpublished observations) indicate, in combination with the present observations on monkey liver cultures, that the rate of hemopexin production is higher in fetal than in adult liver tissue. Stimulation of serum protein synthesis in monkey and rat liver during liver regeneration has also been reported $(14,27)$. In addition, in hepatoma cell lines the rate of albumin and of transferrin synthesis per cell was higher during the $\log$ than during the stationary growth phase (28). It is not at all clear what stimulus mediates the effect of paratyphoid vaccine injection on serum protein synthesis in the liver. It appears that, with the liver of rodents $(13,14)$, it is a more general effect on all serum protein synthesis than can be deduced from observations on serum protein levels in the human during various disease states (29).

Transferrin is also produced by the liver, and by a purely epithelial rat hepatoma cell line (30), therefore presumably by liver parenchymal cells. In addition, however, in the mouse, rat, and neonatal rabbit and in the present studies also in the monkey, transferrin is 
produced by lymphoid tissue $(11,15,16,31)$. Earlier investigations had established that the cell in lymphoid tissue of some rodents responsible for this production is most likely the macrophage (15). The present studies reveal additional sites of transferrin synthesis. Among these are the submaxillary gland (rabbit, monkey), lactating mammary gland (rabbit, mouse), ovary (rabbit, mouse), and testis (rabbit, monkey, mouse). The cell type responsible for its synthesis in all these organs has not been established, but it should be pointed out that transferrin synthesis was never found in fibroblastic cell lines (30) and is therefore not likely to be a general property of mesenchymal tissue. The oviduct's synthesis of conalbumin (32), an egg white protein of identical polypeptide chain as chicken serum transferrin (32), may correspond to the synthesis of transferrin by the reproductive organs in mammals. An additional site of transferrin synthesis described by Gitlin and Kitzes is the yolk sac in the fetal rat and chick embryo (33). It is of interest that another iron-binding protein, lactoferrin, has also been found to be synthesized by salivary gland (34).

\section{ACKNOWLEDGMENTS}

This work was supported by grants no. AI-3076, no. HD04445, and no. HE-08660 from the U. S. Public Health Service.

\section{REFERENCES}

1. Muller-Eberhard, U., J. Javid, H. H. Liem, A. Hanstein, and M. Hanna. 1968. Plasma concentrations of hemopexin, haptoglobin and heme in patients with various hemolytic diseases. Blood J. Hematol. 32: 811.

2. Sears, D. A. 1968. Plasma heme-binding in patients with hemolytic disorders. J. Lab. Clin. Med. 71: 484.

3. Eyster, M. E., T. S. Edgington, H. H. Liem, and U. Muller-Eberhard. (1972). Plasma hemopexin levels following aortic valve replacement: a valuable screening test for assessing the severity of cardiac hemolysis. J. Lab. Clin. Med. $80: 112$.

4. Koskelo, P., I. Toivonen, and P. Rintola. 1970. The binding of ${ }^{14} \mathrm{C}$-labeled porphyrins by plasma proteins. Clin. Chim. Acta. 29: 559.

5. Amin, A. H., H. G. Clarke, T. Freeman, I. M. MurrayLyon, P. M. Smith, and R. Williams. 1970. Studies by quantitative immunoelectrophoresis on iron binding proteins in haemochromatosis. Clin. Sci. (Oxf.). 38: 613 .

6. Cleve, H., K. Alexander, H. J. Mitzkat, P. Nissen, and I. Salzmann. 1968. Serumglykoproteine beim Diabetes mellitus; quantitative immunologische Bestimmung von saurem $\alpha_{1}$-Glykoprotein, Gc, $\alpha_{2}$-Makroglobulin und Hämopexin bei Diabetikern mit und ohne Angiopathien. Diabetologia. 4: 48.

7. Snyder, S., and G. Ashwell. 1971. Quantitation of specific serum glycoproteins in malignancy. Clin. Chim. Acta. 34 : 449.

8. Laurell, C. B. 1947. Studies on the transportation and metabolism of iron in the body. Acta Physiol. Scand. 14(Suppl.) : 46.
9. Muller-Eberhard, U. 1970. Hemopexin. N. Engl. J. Med. 283: 1090.

10. Gitlin, D., and A. Biasucci. 1969. Development of $\gamma \mathrm{G}$, $\gamma \mathrm{A}, \gamma \mathrm{M}, \beta_{1 \mathrm{c}} / \beta_{1 \Delta}, \mathrm{C}^{\prime} 1$ esterase inhibitor, ceruloplasmin, transferrin, hemopexin, haptoglobin, fibrinogen, plasminogen, $\alpha_{1}$-antitrypsin, orosomucoid, $\beta$-lipoprotein, $\alpha_{2}$ macroglobulin, and prealbumin in the human conceptus. J. Clin. Invest. 48: 1433.

11. Hochwald, G. M., G. J. Thorbecke, and R. Asofsky. 1961. Sites of formation of immune globulins and of a component of $\mathrm{C}_{3}^{\prime}$. I. A new technique for the demonstration of the synthesis of individual serum proteins by tissue in vitro. J. Exp. Med. 114: 459.

12. Asofsky, R., and G. J. Thorbecke. 1961. Sites of formation of immune globulins and of a component of $\mathrm{C}_{3}^{\prime}$ II. Production of immunoelectrophoretically identified serum proteins by human and monkey tissues in vitro. J. Exp. Med. 114: 471.

13. Williams, C. A., R. Asofsky, and G. J. Thorbecke. 1963. Plasma protein formation in vitro by tissues from mice infected with staphylococci. J. Exp. Med. 118: 315 .

14. Hurlimann, J., G. J. Thorbecke, and G. M. Hochwald. 1966. The liver as the site of C-reactive protein formation. J. Exp. Med. 123: 365.

15. Stecher, V. J., and G. J. Thorbecke. 1967. Sites of synthesis of serum proteins. I. Serum proteins produced by macrophages in vitro. J. Immunol. 99: 643.

16. Stecher, V. J., and G. J. Thorbecke. 1967. $\beta_{\mathbf{1 c}}$ and immune globulin formation in vitro by tissues from germfree and conventional rodents of various ages. Immunology. $12: 475$.

17. Thorbecke, G. J., J. Hurlimann, and A. M. Silverstein. 1967. Production of fetuin and other serum proteins by fetal sheep liver in vitro. Proc. Soc. Exp. Biol. Med. $126: 816$.

18. Thorbecke, G. J., G. M. Hochwald, R. Van Furth, H. J. Müller-Eberhard, and E. B. Jacobson. 1965. Problems in determining sites of synthesis of complement components. Complement Ciba Found. Symp. 99.

19. Hochwald, G. M, E. B. Jacobson, and G. J. Thorbecke. 1964. $C^{14}$-amino acid incorporation into transferrin and $\beta_{2 \mathrm{~A}}$-globulin by ectodermal glands in vitro. Fed Proc. 23: 557 .

20. Thorbecke, G. J., G. M. Hochwald, and C. A. Williams. 1971. Autoradiography of antigen-antibody reactions in gels. Meth. Immunol. Immunochem. 3: 343.

21. Thorbecke, G. J., and G. M. Hochwald. 1968. Use of radioimmunoelectrophoresis for the study of serum protein and antibody synthesis in vitro. In Radioisotopes in Medicine: In Vitro Studies. R. L. Hayes, F. A. Goswitz, B. E. P. Murphy, and E. B. Anderson, editors. U. S. Atomic Energy Commission, Oak Ridge, Tenn. 589.

22. Clausen, J., R. Rask-Nielsen, H. E. Christensen, and T. Munkner. 1960. Two transplantable mouse hepatomas associated with an increase of metal-combining $\beta$ globulin (transferrin) in serum. Cancer Res. 20: 178.

23. Uriel, J. 1960. Les réactions de charactérization des constituants protéiques après electrophorèse ou immunoelectrophorèse en gélose. In Analyse Immunoélectrophorétique. $P$. Grabar and $P$. Burtin, editors. Masson et Cie, Paris. 33.

24. Hrkal, Z., and U. Muller-Eberhard. 1971. Partial characterization of the heme-binding serum glycoproteins rabbit and human hemopexin. Biochemistry. 10: 1746. 
25. Smibert, E., H. H. Liem, and U. Muller-Eberhard. 1972. Studies on the induction of serum hemopexin by pentobarbital and polycyclic hydrocarbons. Biochem. Pharmacol. 21 : 1753.

26. Heimburger, N., K. Heide, H. Haupt, and H. E. Schultze. 1964. Bausteinanalysen von Humanserumproteinen. Clin. Chim. Acta. 10: 293.

27. Majumdar, C., K. Tsukada, and I. Lieberman. 1967. Liver protein synthesis after partial hepatectomy and acute stress. J. Biol. Chem. $242: 700$.

28. Ohanian, S. H., S. B. Taubman, and G. J. Thorbecke. 1969. Rates of albumin and transferrin synthesis in vitro in rat hepatoma-derived $\mathrm{H}_{4} \mathrm{II}-\mathrm{EC}_{3}$ cells. J. Natl. Cancer Inst. 43: 397.

29. Kushner, I., T. S. Edgington, C. Trimble, H. H. Liem, and U. Muller-Eberhard. 1972. Plasma hemopexin homeostasis during the acute phase response. J. Lab. Clin. Med. 80 : 18.
30. Stecher, V. J., and G. J. Thorbecke. 1967. Sites of synthesis of serum proteins. III. Production of $\beta_{1 \mathrm{C}}, \beta_{1 \mathrm{k}}$, and transferrin by primate and rodent cell lines. $J$. Immunol. 99 : 660 .

31. Phillips, M. E., and G. J. Thorbecke. 1966. Studies on the serum proteins of chimeras. I. Identification and study of the site of origin of donor type serum proteins in adult rat-into-mouse chimeras. Int. Arch. Allergy Appl. Immunol. 29: 553.

32. Williams, J. 1962. A comparison of conalbumin and transferrin in the domestic fowl. Biochem. J. 83: 355.

33. Gitlin, D., and Kitzes, J. 1967. Synthesis of serum albumin, embryo-specific $\alpha$-globulin and conalbumin by the chick yolk sac. Biochem. Biophys. Acta. 147: 334.

34. Hurlimann, J., and C. Zuber. 1968. In vitro protein synthesis by human salivary glands. II. Synthesis of proteins specific to saliva and other excretions. Immunology. $14: 819$. 